\title{
MOTIVATION FOR PHYSICAL CULTURE AS FACTOR OF STUDENTS' FUNCTIONAL STATE OPTIMIZATION
}

Lachno O.G.

Prydniprovs'ka State Academy of Civil Engineering and Architecture

\begin{abstract}
Purpose: to analyze students' attitude to physical education classes; to compare motivation for physical education of $1^{\text {st }}$ and $4^{\text {th }}$ year students. Material: 100 students of $17-22$ years' age participated in the research. All they were questioned. Results: In the whole, boys have positive attitude to sport practicing but some of them can have harmful habits. The attitude to sport practicing of most of girls changes with age. It was found that biological age of students significantly exceeds passport age. Biological age of senior students it reduces to some extent, in comparison with junior students. It was also found that in process of studying at HEE students' motivation for sport practicing changes to positive side. It witnesses about formation of student positive attitude to physical education in general. Conclusions: we have shown that there is a demand in strengthening of motivation for physical culture classes and further formation positive attitude to them with increasing of students' knowledge about physical education.
\end{abstract}

Key words: student, health, biological age, physical education.

\section{Introduction}

Health is main indicators of physical culture in society $[1 ; 2 ; 3 ; 4]$. Mechanisms of human motor functioning and health are open in researches by T.Yu. Krutsevych (2005) [18], V.A. Kashuba, S.M. Futornoy, Yt.V. Andreyeva (2012) [12], G.L. Apanasenko (2003) [2]. Motor functioning is biological demand of every living organism, integral part of healthy life style, one of the most important social-biological factors. Such factors form human organism, ensure balance between organism and environment; facilitate perfection of regulation mechanisms of metabolic adaptation processes $[7 ; 8 ; 9 ; 10 ; 11]$.

Youth's health was analyzed in a number of works of such scientists as F.I. Sobianin, V.I. Bocharov, I.A. Kulikov (2011) [19]; R. Podstavka, D. Zvolynska, R. Urbanska-Gyzynska, D. Novoselska- Svadba (2013) [20]; Carlos Eduardo Da Costa, Vinicius Barroso Hirota, Ademir De Marco. (2015) [25]; David Hortigüela-Alcalá, Ángel Pérez-Pueyo, José Moncada-Jiménez (2015) [26]. They found that most of HEEs students have unsatisfactory health due to wrong regiment of labor and rest, negative habits and against the background of physical inactivity.

Clear interconnection between health and motor regimeД, organization and methodic of physical education specialists has been proved $[21 ; 22 ; 23 ; 29 ; 32 ; 33]$. Most of students have unsatisfactory health due to wrong regime of works and rest, using of alcohol, nicotine and drugs, against the background of restricted motor functioning $[24 ; 30 ; 31 ; 35]$. Scientific-technical progress, mechanization and automation of production, development of transport servicing of population sharply decreased muscular functioning of person on the one hand and significantly increased nervous-psychic loads on the other hand $[2 ; 3 ; 36]$. Practicing of physical exercises, outdoor and sport games strengthen nervous system $[13 ; 14 ; 34]$, release tension, create cheerful mood. It facilitates increasing of workability $[15 ; 16 ; 17 ; 36]$.

That is why physical training of students is one of main tasks of higher educational establishments.

However, many authors noticed deficit of motivation for physical exercises' healthy life style practicing $[21 ; 33 ; 35]$. In this connection it is rather important to reveal dependences between education progress in physical culture and level of students' functional state. It would permit to substantiate need in increasing students' knowledge of theoretical principles of physical education and increase their motivation for physical culture.

Purpose, tasks of the work, material and methods

The purpose of the research is to analyze students' attitude to physical education classes; to compare motivation for physical education of $1^{\text {st }}$ and $4^{\text {th }}$ year students.

The methods of the research: analysis of scientific, methodic literature; questioning, determination of biological age as level of health. In questioning 100 respondents participated $-50 \%$ of boys and $50 \%$ of girls. By

(c) Lachno O.G., 2015

http://dx.doi.org/10.15561/20755279.2015.0505 
their age they were: up to 19 years old - 25 boys and 25 girls of $1^{\text {st }}$ year; from 20 to 22 years old - also 25 boys and 25 girls of $4^{\text {th }}$ year.

\section{Results of the researches}

Students' questioning showed that $17 \%$ of students have high progress, $69 \%$ - average and $14 \%$ have low level of progress. Surely, the questioning data can not be generalized for all youth of Dnepropetrovsk, but they permit to find general characteristics of students' attitude to sports.

The following indicators of students' activity were chosen as the main:

- Social activity (participation in mass-sport measures of HEE);

- Conditions for practicing of physical culture in HEE;

- Influence of student's surrounding on hid attitude to physical culture;

- Students' assessment of their way of life;

- Students' belonging to sports;

- Students' awareness about usefulness of physical culture.

Questioning about students' involvement in mass-sport work showed that majority of students ignore such measures. Only little part participates in them. The least quantity is members of HEE combined team. Quantity of boys, involved in sport measures, is bigger than quantity of girls. Students with average level of educational progress are the most interested in mass-sport measures.

It was found that one third of students consider themselves to be people of healthy life style. The forth part of students think that they practice healthy life style. The second one third can not answer this question. There are much more girls (in contrast to boys), who consider themselves to be practicing healthy life style. Dependence of progress level on life style showed that students with high and average progress think that their way of life is favorable for health.

Only one forth part of he questioned practices a kind of sports (17\%). This is the percentage of students, who got the highest mark. And the biggest amount of these students is boys.

Analysis of physical culture classes' attendance and conditions of studying at HEEs showed the following: $86 \%$ of students attend physical culture classes systemically. These students can compose morning exercises' complex, choose place for morning exercises, can practice physical exercises independently. Questioning of $1^{\text {st }}$ year boy students showed that most of them (68\%) got mark "good", 20\% - got mark "average" and $12 \%$ - "excellent". It witnesses that great number of boys (more than half of the questioned) practice physical exercises and in general have positive attitude to sports. These students have general knowledge of physical education and valueology, but they did not get the highest mark due to presence of harmful habits.

"Average" mark was received by $20 \%$ of the questioned. It means that they have some minimal knowledge in the field of physical education. Their attendance of physical culture trainings is not regular. $12 \%$ of $1^{\text {st }}$ year boy students got "excellent" mark. They regularly practice physical exercises or some kind of sports. Such students have deep knowledge of their organism.

Besides, we found that the highest percentage of the questioned $1^{\text {st }}$ year girl students got "good" mark $(60 \%)$. It witnesses about their, in the whole, positive attitude to physical culture and about their having basic knowledge of hygiene, healthy eating and physical functioning.

$32 \%$ of girls received "average" mark. It witnesses about insufficient knowledge in physical culture and valueology field as well as about possible harmful habits or dismissive attitude to physical culture.

Only $8 \%$ of $1^{\text {st }}$ year girl students received "excellent" mark. They attend physical culture classes regularly; have correct eating and no harmful habits; they have theoretical knowledge of physical culture and sports principles.

Comparison of boys' and girls' questioning results permitted to state: boys have better knowledge and are more involved in physical education. It can be connected with girls' less interest in sport games, which are usually practiced in HEE.

In comparison with $1^{\text {st }}$ year girl students, $4^{\text {th }}$ year girls received much better marks. From it we can conclude that they have better knowledge of physical culture and valueology. It can be explained by the fact that with age girls' attitude to their health becomes more serious. 
Only $4 \%$ of respondents received the worst marks. "Good" marks were got by $80 \%$ of the questioned. It is more than half of $4^{\text {th }}$ year girl students. Most of themo have knowledge of valueology, do not miss physical culture classes and understand significance of healthy life style.

"Excellent" was received by $16 \%$ of $4^{\text {th }}$ year girl students. These girls have the most complete knowledge of valueology, do not miss physical culture classes; practice healthy life style and some kind of sports.

$4^{\text {th }}$ year boy students showed the best indicators of all 4 groups of the questioned. It can be explained by the fact that with age boys' attitude to their health becomes more responsible and they practice sports more often. $68 \%$ of $4^{\text {th }}$ year boy students received "good" mark. It can witness that in general boys are more interested in sports than girls.

$32 \%$ of $4^{\text {th }}$ year boy students received "excellent" marks. Such big percentage witnesses about their profound knowledge in sphere of physical culture and valueology as well as about absence of harmful habits. Besides, we can note that all $4^{\text {th }}$ year boy students with mark "excellent" practice some kind of sports by their choice.

Analyzing general data of $1^{\text {st }}$ year students (boys and girls), we received the following results: $26 \%$ received "average" mark, $64 \%$ - "good" and $10 \%$ - "excellent". General indicators of $4^{\text {th }}$ year students are much better. "Excellent" was received by $24 \%$ by students, "good" - by $74 \%$, "average" - only by $2 \%$ of the questioned senior students. Comparison of questioning results of junior and senior students showed that with age there appears positive dynamic of increase of students' knowledge in physical culture and valueology field. It was found that at $4^{\text {th }}$ year of studying less percentage of students have harmful habits, higher percentage practice some certain kind of sports; senior students have higher awareness about healthy life style.

In order to assess health and functional state of students we used methodic by V.P. Voytenko [5; 6].

Table 1. Indicators of $1^{\text {st }}$ year students' physical condition

\begin{tabular}{|c|c|c|c|c|c|}
\hline № & Indicators & & $\bar{x}$ & $\pm S$ & $v \%$ \\
\hline \multirow{2}{*}{1} & \multirow{2}{*}{ Passport age } & girls & 17.6 & 0.69 & 3.9 \\
\hline & & boys & 17.4 & 0.59 & 3.3 \\
\hline \multirow{2}{*}{2} & \multirow{2}{*}{ Biological age } & girls & 35.2 & 5.78 & 17.4 \\
\hline & & boys & 33.1 & 7.4 & 10.2 \\
\hline \multirow{2}{*}{3} & \multirow[t]{2}{*}{ Systolic blood pressure } & girls & 107.5 & 9.2 & 8.6 \\
\hline & & boys & 118.9 & 7.9 & 7.1 \\
\hline \multirow{2}{*}{4} & \multirow{2}{*}{ Diastolic blood pressure } & girls & 61.5 & 8.2 & 13.3 \\
\hline & & boys & 72.4 & 6.2 & 9.4 \\
\hline \multirow{2}{*}{5} & \multirow{2}{*}{ Pulse blood pressure } & girls & 46 & 12.4 & 26.9 \\
\hline & & boys & 57 & 7.4 & 8.3 \\
\hline \multirow{2}{*}{6} & \multirow{2}{*}{ Body mass } & girls & 54.5 & 3.2 & 5.9 \\
\hline & & boys & 62.8 & 5.4 & 7.8 \\
\hline
\end{tabular}


Analysis of students' biological age showed that only $2 \%$ of the tested group's girls have blood pressure corresponding to age standard. This indicator of boys is much better $(60 \%)$. We connect this fact with the fact that girls of this age group are more bent to hypotension.

Table 2. Indicators of $4^{\text {th }}$ year students' physical condition

\begin{tabular}{|c|c|c|c|c|c|}
\hline № & Indicators & & $\bar{x}$ & $\pm S$ & $v \%$ \\
\hline \multirow{2}{*}{1} & \multirow{2}{*}{ Passport age } & girls & 21.6 & 0.63 & 3.4 \\
\hline & & boys & 21.4 & 0.76 & 2.8 \\
\hline \multirow{2}{*}{2} & \multirow{2}{*}{ Biological age } & girls & 34.5 & 6.13 & 20.1 \\
\hline & & boys & 32.3 & 5.34 & 18.2 \\
\hline \multirow{2}{*}{3} & \multirow[t]{2}{*}{ Systolic blood pressure } & girls & 109.5 & 6.9 & 6.3 \\
\hline & & boys & 116.7 & 6.3 & 5.2 \\
\hline \multirow{2}{*}{4} & \multirow{2}{*}{ Diastolic blood pressure } & girls & 63 & 6.7 & 10.6 \\
\hline & & boys & 72 & 5.9 & 8.9 \\
\hline \multirow{2}{*}{5} & \multirow{2}{*}{ Pulse blood pressure } & girls & 47 & 12.5 & 26.6 \\
\hline & & boys & 60 & 6.2 & 7.8 \\
\hline \multirow[b]{2}{*}{6} & \multirow[b]{2}{*}{ Body mass } & girls & 54.5 & 3.2 & 5.9 \\
\hline & & boys & 63.0 & 5.9 & 7.1 \\
\hline
\end{tabular}

\section{Discussion}

Results of our researches confirmed the data of other authors about interconnection of students' somatic health and physical condition (G.L. Apanasenko et al., 2003 [2]; L.N. Barybina et al., 2012 [4]; Iermakov S.S. et al., 2012 [7]). The received by us results also supplement our previous research [11].

Analyzing $4^{\text {th }}$ year students' indicators we can note positive age dynamic. Though blood pressure did not changed noticeably, biological age reduced to some extent. We connect this fact with more fair attitude to physical education and own health in the whole.

It would be logical to assume that rising of $4^{\text {th }}$ year students' progress in physical education, in comparison with $1^{\text {st }}$ year students, is connected with increasing of their motivation for physical culture. The received results witness about effectiveness of organizational work on physical education in the researched HEE. Strengthening of motivation for physical culture indirectly influences on students' functional state. For increasing of students' motivation for physical culture it is purposeful to apply modern informational technologies, that is described in the works of Al-Ravashdeh Abdel Baset, Kozina Zh.L., Kramskoy S.I., Bazilyuk T.A. (2015) [21]; Ilnitskaya A.S. Kozina Zh.L., Korobejnik V.A., Ilnickiy S.V., Cieślicka Mirosława, Stankiewicz Błażej, Pilewska Wiesława (2014) [35].

\section{Conclusions}

1. The questioning revealed that most of $1^{\text {st }}$ year $(68 \%)$ and $4^{\text {th }}$ year $(68 \%)$ boy students received "good" mark and practice physical exercises, however, they can have harmful habits. In the whole, boys have positive attitude to sports. Attitude to sport's practicing of most of girls change with age. "Good" mark was received by $60 \%$ of $1^{\text {st }}$ year girl students and $80 \%$ of $4^{\text {th }}$ year girl students.

2. It was found that students' biological age significantly exceeds passport age. Concerning senior students, in comparison with junior students, it reduces to some extent.

3. In the process of studying students' motivation for physical education changes in positive side. It witnesses about formation of students' positive attitude to sports in the whole.

The prospects of further researches imply working out of technologies for increasing of students' motivation for physical culture.

\section{Acknowledgement}

The research was conducted in compliance with the following: 
- $\quad$ "Combined plan of scientific-research work in sphere of physical culture and sports for 20112015 " by topic 2.4 "Theoretical-methodic principles of individualization in physical education and sports" (state registration № 0112U002001);

- $\quad$ Scientific-research work, financed by state budget of Ministry of education and science of Ukraine for 2013-2014: "Theoretical-methodic principles of application of informational, pedagogic and medicalbiological technologies for formation of healthy life style” (State registration № 0113U002003)

- Scientific-research work, financed by state budget of Ministry of education and science of Ukraine for 2015-2016: "Theoretical-methodic principles of application of informational, pedagogic and medical-biological technologies for motor and spiritual development and formation of healthy life style".

\section{Conflict of interests}

The author declares that there is no conflict of interests.

\section{References:}

1. Adashevskij VM, Iermakov SS, Zielins'ki Eva. Opredelenie energeticheskikh i silovykh kharakteristik pri khod'be so vspomogatel'nymi sredstvami ottalkivaniia (palkami) ot nizhnej opory [Energy and power characteristics of walking with auxiliary pushing off means (sticks) from ground]. Physical education of students, 2012;3:5-8. (in Russian)

2. Apanasenko GL, Kozakevich VK, Korovina LD. Uroven' somaticheskogo zdorov'ia, ego sviaz' s fizicheskim razvitiem i prognozirovanie zabolevaemosti podrostkov [Somatic health,; its connection with physical condition and prognostication of adolescents' morbidity]. Valeologiia, 2003;1:19-24. (in Russian)

3. Bal'sevich VK. Infrastruktura vysokoeffektivnogo fizicheskogo vospitaniia $v$ obshcheobrazovatel'noj shkole: metodologiia proektirovaniia i ekspluatacii [Infrastructure of highly effective physical education in comprehensive school: methodology of projecting and operation]. Fizicheskaia kul'tura: vospitanie, obrazovanie, trenirovka, 2003;4:3-12. (in Russian)

4. Barybina LN, Semashko SA, Krivencova EV. Primenenie individual'nogo podkhoda pri provedenii zaniatij po aerobike so studentami raznogo urovnia podgotovlennosti [Individual approach to aerobic trainings with students of different fitness levels]. Physical education of students, 20125:9-13. (in Russian)

5. Vojtenko VP. Biologicheskij vozrast. Biologiia stareniia [Biological age. Biology of ageing]. Leningrad, Science; 1982. (in Russian)

6. Vojtenko VP. Biologicheskij vozrast. Fiziologicheskie mekhanizmy stareniia [Biological age. Physiological mechanisms of ageing]. Moscow: Science; 1982. (in Russian)

7. Iermakov SS, Ivashchenko SN, Guzov VV. Osobennosti motivacii studentov s primeneniem individual'nykh programm fizicheskoj samopodgotovki [Motivation of students with application of physical self training's individual programs]. Physical education of students, 2012;4:59-61. (in Russian)

8. Ermakov SS, Krivencova IV, Minenok AA. Osobennosti fizicheskogo vospitaniia studentov special'noj medicinskoj gruppy v pedagogicheskom vuze [Physical education of special health group students in pedagogic HEE]. Visnik Chernigivs'kogo derzhavnogo pedagogichnogo universitetu imeni T.G.Shevchenka, 2013;2(107):193-196. (in Russian)

9. Iermakov SS. Biomekhanichni modeli udarnikh rukhiv u sportivnikh igrakh u konteksti vdoskonalennia tekhnichnoi pidgotovki sportsmeniv [Bio-mechanical models of striking movements in sport games in context of perfection of sportsmen's skillfulness]. Teoriia ta metodika fizichnogo vikhovannia, 2010;4:1118. (in Ukrainian)

10. Iermakov SS. Naukovi informacijni aspekti fizkul'turnoi osviti [Scientific and informational aspects of physical culture]. II elektronna naukova konferenciia, 18 travnia 2006 r., m. Kharkiv "Aktual'ni problemi fizkul'turnoi osviti" [2nd electronic scientific conference, May 18, 2006, Kharkov "Important problems of physical culture education"]. Kharkiv; OVS: 2006. P. 12-14. (in Ukrainian)

11. Ilnitskaya AS, Kozina ZhL, Lakhno EG, Ilnitskaya LV, Cieślicka Mirosława, Stankiewicz Błaźej, Pilewska Wiesława. Students' attitude to the possibility of applying modern information and communication technologies in the educational process in physical education. Physical Education of Students, 2014;2:1824. http://dx.doi.org/10.6084/m9.figshare.906369 
12. Kashuba VA, Futornyj CM, Andreeva EV. Sovremennye podkhody k zdorov'esberezheniiu studentov v processe fizicheskogo vospitaniia [Modern approaches to students' health protection in process of physical education]. Physical education of students, 2012;7:50-58. (in Russian)

13. Kozina ZhL. Analiz i obobshchenie rezul'tatov prakticheskoj realizacii koncepcii individual'nogo podkhoda $\mathrm{v}$ trenirovochnom processe $\mathrm{v}$ sportivnykh igrakh [Analysis and generalization of results of practical realization of individual approach conception in sport games' training]. Physical education of students, 2009;2:34-47. (in Russian)

14. Kozina ZhL, Sliusarev VF, Volkov IeP. Efektivnist' zastosuvannia netradicijnoi formi autogennogo trenuvannia dlia vidnovlennia pracezdatnosti basketbolistiv [Effectiveness of application of non traditional autogenic training for recreation of basketball players' workability]. Pedagogics, Psychology, medicalbiological problems of physical training and sports, 2001;14:8-15. (in Ukrainian)

15. Kozina ZhL. Sistema individualizacii podgotovki sportsmenov v igrovykh vidakh sporta [System of individualization of sportsmen's training in game kinds of sports]. Lambret Academic Publishing Russia; 2011. (in Russian)

16. Kozina ZhL. Rezul'taty razrabotki i prakticheskogo primeneniia algoritma sistemnogo analiza $\mathrm{v}$ nauchnykh issledovaniiakh $\mathrm{v}$ oblasti sportivnykh igr [Results of development and practical application of systemic analysis algorithm in scientific researches on sport games]. Slobozhans'kij naukovo-sportivnij visnik, 2006;9:157-165. (in Russian)

17. Kozina ZhL, Popova N. Faktorna struktura zagal'noi fizichnoi pidgotovlenosti divchatok $11-15$ rokiv [Factorial structure of 11-15 years old girls' general physical fitness]. Teoriia ta metodika fizichnogo vikhovannia, 2013;4:48-52. (in Ukrainian)

18. Krucevich T, Nesterenko A. Motivacionnye prioritety zdorovogo obraza zhizni studentok vuzov [Motivation priorities of healthy life style of HEEs girl students]. IX Mizhnarodnij naukovij kongress "Olimpijs'kij sport $i$ sport dlia vsikh» [9th International scientific congress "Olympic sports and sports for all”, Kyiv, September 20-23, 2005]. Kiev; 2005. P. 581. (in Russian)

19. Sobianin FI, Bocharova VI, Kulikov IA. Vyiavlenie effektivnykh sredstv fizicheskoj kul'tury, sposobstvuiushchikh povysheniiu umstvennoj rabotosposobnosti studentov vuzov [Determination of effective means of physical culture, which facilitate increasing of HEE students' mental workability]. Kul'tura fizicheskaia i zdorov'e, 2011;11:29-32. (in Russian)

20. Podstawski Robert, Zwolińska Danuta, Urbańska-Gizińska Renata, Nowosielska-Swadźba Danuta, The effect of learning environment factors on biological development of first year students. Physical Education of Students, 2013;6:103-109. http://dx.doi.org/10.6084/m9.figshare.845594

21. Al-Ravashdeh Abdel Baset, Kozina ZhL, Kramskoy SI, Bazilyuk TA. Application of interdisciplinary connections and information technologies for development of motor skills in light athletic of girls - senior form pupils. Pedagogics, psychology, medical-biological problems of physical training and sports, 2015;8:9-16. http://dx.doi.org/10.15561/18189172.2015.0802

22. Al-Ravashdeh Abdel Baset, Kozina ZhL, Bazilyuk TA, Ilnickaya AS. Influence of skills'training methodic with the application of interdisciplinary connections on motor fitness of senior pupils in light athletic. Pedagogics, psychology, medical-biological problems ofphysical training and sports, 2015;9:3-11. http://dx.doi.org/10.15561/18189172.2015.0901

23. Alptekin Erkollar, Oberer BJ. Putting Google+ to the Test: Assessing Outcomes for Student Collaboration, Engagement and Success in Higher Education. Procedia - Social and Behavioral Sciences, 2013;83(4):185-189.

24. Artur Rocha, Angelo Martins, José Celso Freire Junior et al. Innovations in health care services: The CAALYX system. International Journal of Medical Informatics, 2013;82(11):e307-e320.

25. Carlos Eduardo Da Costa, Vinicius Barroso Hirota, Ademir De Marco. Motivational goals orientation in Physical Education classes of elementary education. Journal of Physical Education and Sport, $2015 ; 15(2): 167-171$. 
26. David Hortigüela-Alcalá, Ángel Pérez-Pueyo, José Moncada-Jiménez. An analysis of the responsibility of physical education students depending on the teaching methodology received. Journa of Physical Education and Sport, 2015,15(2):202 - 207.

27. Prusik Krzysztof, Prusik Katarzyna, Kozina ZhL, Iermakov SS. Features of physical development, physical preparedness and functional state of boys and girls - students of Polish higher educational establishments. Physical Education of Students, 2013;1:54-61. http://dx.doi.org/10.6084/m9.figshare.96415

28. Frank Hookin Fu, Linxuan Guo, Yanpeng Zang An overview of health fitness studies of Hong Kong residents from 2005 to 2011. Journal of Exercise Science \& Fitness, 2012;10(2):45-63.

29. Kozina ZhL, Al-Ravashdeh Abdel Baset, Kramskoy SI, Ilnickaya AS. Methodic of skills' formation of light athletics motor actions with the help of inter-disciplinary communications and informational technologies, worked out for senior form pupils. Pedagogics, psychology, medical-biological problems of physical training and sports 2015;7:17-24. http://dx.doi.org/10.15561/18189172.2015.0703

30. Mikael Bäckström, Mats Tinnsten, Andrey Koptyug. Sports Technology Education at Mid Sweden University. Procedia Engineering, 2013;60:214-219.

31. Hribovska Iryna, Danylevych Myroslava, Ivanochko Victoria, Shchur Lydia. Organizational conditions of healthy lifestyle promotion for arts students. Journal of Physical Education and Sport, 2015;15(2):218 224.

32. Prusik Katarzyna, Iermakov SS, Kozina ZhL. Indexes of physical development, physical preparedness and functional state of polish students. Pedagogics, psychology, medical-biological problems of physical training and sports, 2012;12:113-122.

33. Patrick Waterson. Health information technology and sociotechnical systems: A progress report on recent developments within the UK National Health Service (NHS). Applied Ergonomics, 2014;45(2):150-161.

34. Kozina Zhanneta, Sobko Irina, Bazulyk Tatyana, Ryepko Olena, Lachno Olena, Ilintskaya Anna. The applying of the concept of individualization in sport. Journal of Physical Education and Sport, 2015;15(2):172 - 177. http://dx.doi.org/10.7752/jpes.2015.02027

35. Ilnitskaya A.S. Kozina Zh.L., Korobejnik V.A., Ilnickiy S.V., Cieślicka Mirosława, Stankiewicz Błażej, Pilewska Wiesława. The method of application of health systems Bodyfex and Pilates in physical education of students. Pedagogics, psychology, medical-biological problems of physical training and sports, 2014;2:25-32. http://dx.doi.org/10.6084/m9.fgshare.923510

36. Kozina ZhL, Lakhno EG, Moskalets TV, Kondak NN. The system of integral development of children at the age of 1-5 years with the use of technical devices. Pedagogics, psychology, medical-biological problems of physical training and sports, 2011;9:61-68. 


\section{Information about the author:}

Lachno O.G.; http://orcid.org/0000-0002-5845-5337; lahnushechka@rambler.ru; Prydniprovs'ka State Academy of Civil Engineering and Architecture; Chernyshevsky, 24a, Dnipropetrovsk. 49600, Ukraine.

Cite this article as: Lachno O.G. Motivation for physical culture as factor of students' functional state optimization. Physical education of students, 2015;5:31-38. http://dx.doi.org/10.15561/20755279.2015.0505

The electronic version of this article is the complete one and can be found online at: http://www.sportpedu.org.ua/html/arhive-e.html

This is an Open Access article distributed under the terms of the Creative Commons Attribution License, which permits unrestricted use, distribution, and reproduction in any medium, provided the original work is properly cited (http://creativecommons.org/licenses/by/4.0/deed.en).

Received: 16.08 .2015

Accepted: 29.08.2015; Published: 02.09.2015 